\title{
Regenerated trees in farmers' fields increase soil carbon across the Sahel
}

\author{
J. Bayala (1D) J. Sanou $\cdot$ H. R. Bazié $\cdot$ R. Coe $\cdot$ A. Kalinganire $\cdot$ \\ F. L. Sinclair
}

Received: 30 January 2019/Accepted: 20 May 2019/Published online: 25 May 2019

(C) The Author(s) 2019

\begin{abstract}
In the current debate on the role of increase soil carbon in addressing both climate change and food security, there is consensus that farmed lands have the higher potential provided the best management practices are implemented. In the Sahel where farms usually have few sparse old trees with declining soil fertility, there is an ongoing re-greening process with increases in tree cover for which there is still a dearth of quantified information on its impacts on soil properties. This research aimed at filling that gap. We sampled soil using a concentric zone design around
\end{abstract}

J. Bayala $(\square) \cdot$ A. Kalinganire

World Agroforestry (ICRAF), ICRAF-WCA/Sahel Node, BP E5118, Bamako, Mali

e-mail: j.bayala@cgiar.org

J. Sanou

Département Environnement et Forêts, Institut de

l'Environnement et de Recherches Agricoles,

03 BP 7047, Ouagadougou 03, Burkina Faso

H. R. Bazié

Unité de Formation et Recherche en Sciences de la Vie et de la Terre, Université Ouaga I Pr Joseph Ki-Zerbo,

03 BP 7021, Ouagadougou 03, Burkina Faso

R. Coe $\cdot$ F. L. Sinclair

World Agroforestry (ICRAF),

PO Box 30677, Nairobi 00100, Kenya

F. L. Sinclair

School of Environment, Natural Resources and Geography, Bangor University, Gwynedd LLL57 2UW, UK individual trees of dominant species and at different soil depths $(0-10,10-30,30-50$ and $50-70 \mathrm{~cm})$ in four Sahelian countries: Burkina Faso, Mali, Niger and Senegal. The results showed increase total carbon content of the top $0-10 \mathrm{~cm}$ soil, generally with high sand content $(>70 \%)$, ranged from 0.16 to $0.44 \%$ (mean $0.23 \%$ ). Under trees it was a factor $1.04-1.47$ higher than away from trees. Different tree species thrived in different ecological niches and had different impacts on soil properties, highlighting the need for site and species matching in restoration activities. These results suggest that increase vegetation cover in the Sahel is associated with an increase in soil total carbon and this trend is more pronounced on sandy soils.

Keywords FMNR Parkland $\cdot$ Re-greening · Restoration $\cdot$ Soil fertility $\cdot$ Trees

\section{Introduction}

Soil carbon content changes slower than aboveground vegetation, but depends on photosynthesis as source of organic inputs to compensate ongoing decline by decomposition (Bayala et al. 2006; Lorenz and Lal 2014). This is mediated by climate, parent soil materials, texture, topography, time, etc. At fine temporal and spatial scales there is not always a strong relationship between tree cover and soil carbon 
(Doetterl et al. 2016; Mathayo et al. 2016). Terrestrial organic carbon plays an important role in preventing desertification, providing resilience in the face of floods and droughts, as well as mitigating climate change through carbon sequestration and reduction of greenhouse gas (GHG) emissions (Keesstra et al. 2016). Current estimates suggest that trends of tropical deforestation and forest degradation (Gibbs et al. 2010; Green et al. 2013) may globally lead to a $75 \%$ reduction in soil organic carbon (SOC) (Lal 2004; Sanderman et al. 2017).

In semi-arid region of West Africa, soils are inherently poor, very sensitive and vulnerable to degradation mainly due to their low structural stability associated with the type of clay (kaolinite) and low organic matter inputs in most land use types (Bationo et al. 2007). Therefore, enhancing tree cover can help countries of this region in meeting national commitments to land restoration and in their Nationally Determined Contributions to cutting GHG emissions. Increasing soil carbon through restoration activities would also promote soil health and thus contribute to achieving a number of Sustainable Development Goals including 1: No Poverty, 2: Zero Hunger, 3: Good Health and Well-being, 6: Clean Water and Sanitation, 13: Climate Action, 14: Life Below Water and 15: Life on Land (Keesstra et al. 2016). Despite the fact most actors agree that on agriculturally managed lands significant SOC increase can take place, there is still a hot debate about how (which measures) and at which rate it should be done to address both the adaptation and mitigation of climate change. An increase of $0.4 \%$ year $^{-1}$ has been suggested as target, but it is not clear where and how this can be achieved (Minasny et al. 2017). Belowground organic inputs from root and rhizosphere turnover have been postulated as the primary source of SOC in the absence of soil tillage (McCormack et al. 2015).

Increases in crop yield might stem from the provision of supporting ecosystem services by trees and shrubs, such as improving soil carbon and recycling nutrients. At a global scale the increase in woody cover has been reported to be contributing to increasing net carbon uptake trends observed in semiarid ecosystems over the last 3 decades (Ahlström et al. 2015; Poulter et al. 2014). At local scale, fertility gradients around individual mature trees have been well studied (Bayala et al. 2006, 2018; Belsky et al. 1989). However, the effects of different patterns of naturally regenerated trees in crop fields, through Farmers' Managed Natural Regeneration (FMNR), remains under researched. Binam et al. (2015) identified three broad patterns of tree cover in parklands:

1. Low cover, with sparse mature trees, indicating a low level of tree regeneration.

2. A high density of young trees, indicating that a recent change in management has allowed more trees to regenerate.

3. A high density of trees of mixed ages, indicating that the area has been managed for some years to promote regeneration of selected trees.

We used these same categories and refer to them as low, new and high tree cover, respectively. The objective of the study was to understand patterns of soil fertility associated with trees in these contrasting fields and to explore what can be inferred about the effect of changing tree management on soil fertility. With randomised experiments monitored over long periods impractical in this context, we used a crosssectional observational approach that involved sampling locations with different patterns of tree cover, observing differences in soils and then analysing what could be inferred from the resulting data.

\section{Materials and methods}

Study sites

Soil sampling was conducted in four Sahelian countries (Burkina Faso, Mali, Niger and Senegal). The soil surveys were carried out to assess how different tree regeneration categories were affecting soil properties in four villages in each of the four countries, except in Burkina Faso where only three villages were sampled (Fig. 1). Soil was sampled in 20 fields in each of the 15 villages, except for six fields in Maïguiazaoua (Niger) that were not accessible at the time of soil sampling during the rainy season. Hence, a total 294 fields with variable area $(<0.25$ ha to $>10$ ha) were surveyed. Sampled fields were generally managed as a single unit by farmers. Within these fields there was no tradition of managing areas under trees differently from those further away from trees.

In each sampled field the dominant tree species was identified. Fourteen species occurred frequently 


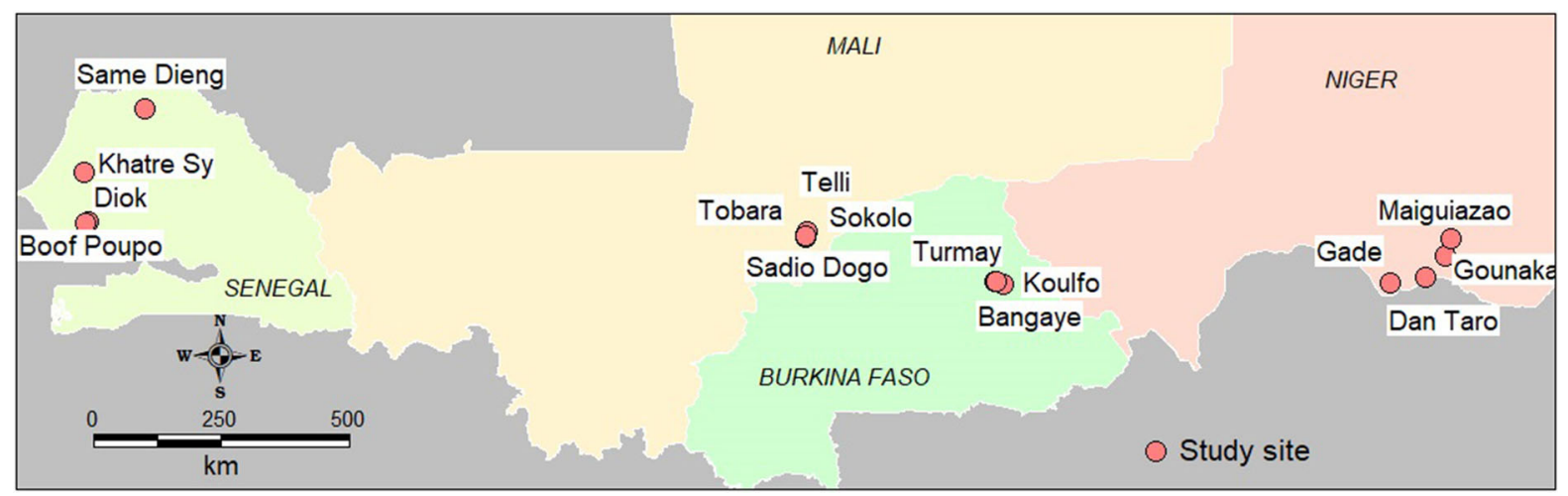

Fig. 1 Location of the soil sampling villages in the four Sahelian countries (Burkina Faso, Mali, Niger and Senegal) for assessing the impacts of tree regeneration on soil properties

Table 1 Number of fields with each dominant species according to the levels of tree regeneration (Low $=$ few trees with no obvious action to favor regeneration, New = obvious signs of newly regenerated seedlings and High $=$ continuous and intensive tree regeneration) and mean topsoil $(0-10 \mathrm{~cm})$ total carbon values $(\%)$ under tree $(0$-half radius corresponding to $\mathrm{T} 1)$ and the away (T0) from trees of different species in four Sahelian countries (Burkina Faso, Mali, Niger and Senegal)

\begin{tabular}{|c|c|c|c|c|c|c|c|}
\hline \multirow[t]{2}{*}{ Dominant species } & \multicolumn{3}{|c|}{ Level of tree regeneration } & \multicolumn{3}{|c|}{ Average topsoil C (\%) } & \multirow[t]{2}{*}{$\mathrm{n}$} \\
\hline & Low & New & High & T0 & $\mathrm{T} 1$ & Difference & \\
\hline Acacia seyal & 1 & 3 & 3 & 0.214 & 0.217 & 0.003 & 7 \\
\hline Adansonia digitata & 5 & 3 & 1 & 0.222 & 0.209 & -0.013 & 9 \\
\hline Anogeissus leiocarpus & 1 & 3 & 1 & 0.225 & 0.194 & -0.032 & 5 \\
\hline Azadirachta indica & 0 & 1 & 0 & & 0.435 & & 1 \\
\hline Balanites aegyptiaca & 15 & 33 & 11 & 0.174 & 0.199 & 0.025 & 55 \\
\hline Combretum micrantum & 2 & 5 & 16 & 0.139 & 0.18 & 0.041 & 23 \\
\hline Detarium microcarpum & 0 & 1 & 0 & 0.153 & 0.265 & 0.113 & 1 \\
\hline Faidherbia albida & 41 & 20 & 35 & 0.177 & 0.271 & 0.094 & 95 \\
\hline Neocaria macrophylla & 1 & 0 & 0 & 0.211 & 0.378 & 0.167 & 1 \\
\hline Piliostigma reticulatum & 19 & 39 & 18 & 0.146 & 0.195 & 0.050 & 75 \\
\hline Sclerocarya birea & 1 & 3 & 2 & 0.154 & 0.156 & 0.002 & 6 \\
\hline Tamarindus indica & 0 & 1 & 0 & 0.172 & 0.188 & 0.016 & 1 \\
\hline Vitellaria paradoxa & 0 & 4 & 3 & 0.194 & 0.204 & 0.010 & 6 \\
\hline Ziziphus mauritiana & 0 & 1 & 1 & 0.172 & 0.221 & 0.049 & 2 \\
\hline
\end{tabular}

enough as dominant to be included in the analysis (Table 1).

\section{Soil sampling design}

Soil was sampled in $100 \mathrm{~m} \times 100 \mathrm{~m}$ plots in fields $>1$ ha at four sampling points located as shown in Fig. 2a. For fields $<1$ ha, one sampling point was used, on a centrally located 0.25 ha area. In either situation, one sampling point was established under the largest individual tree (having the widest crown) of the most dominant species (species displaying the highest number of individuals in the field of concern); such tree was not necessarily centrally located. The sampling design under each tree was arranged in three concentric zones and depended on the tree size: from tree trunk to half radius of the crown, from half radius to one radius of tree crown and from crown edge to three meters outside the crown corresponding to T1, $\mathrm{T} 2$ and T3, respectively (Fig. 2b). For each individual 

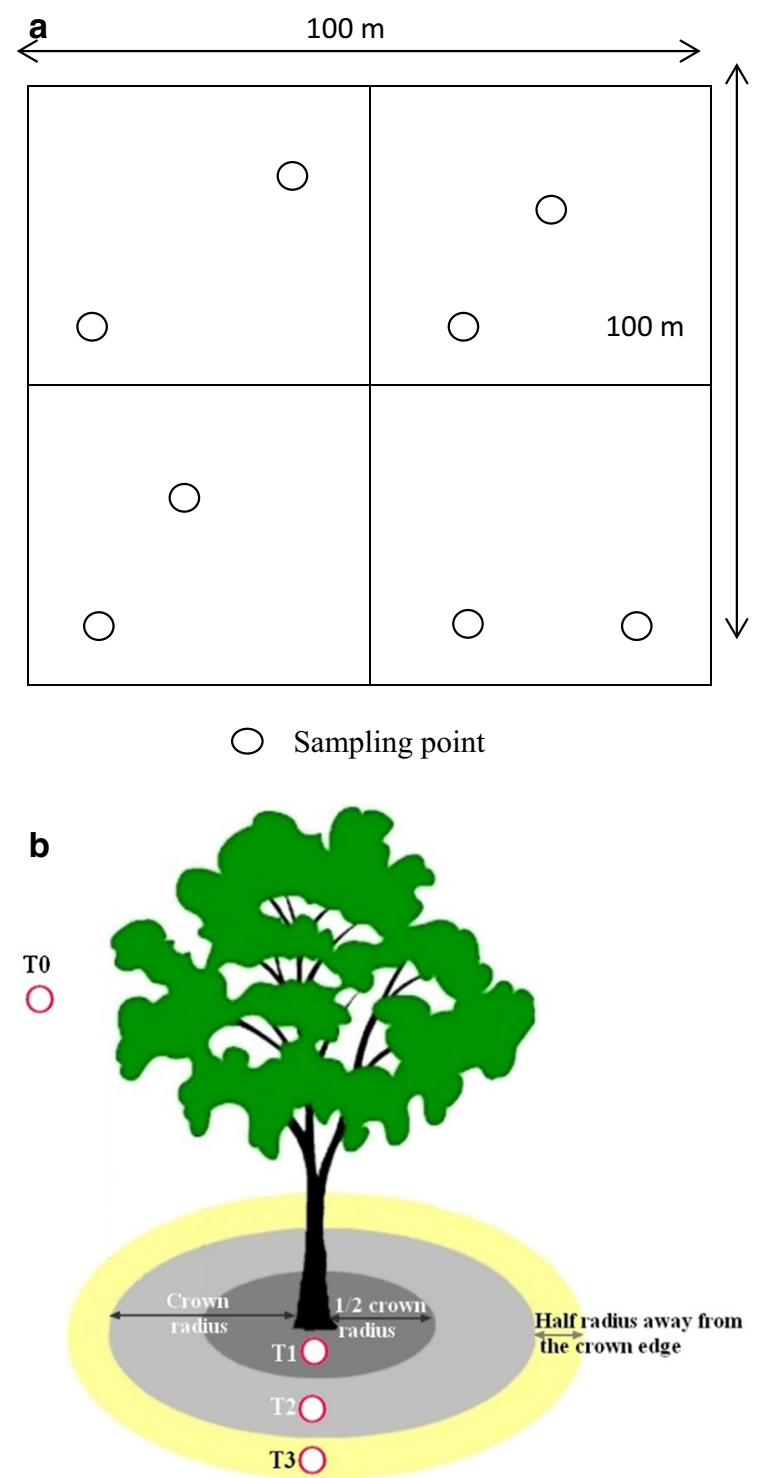

Sampling point

Fig. 2 Soil sampling design per field a under the main common tree species $\mathbf{b}$ for assessing the impacts of tree regeneration on soil properties in four Sahelian countries (Burkina Faso, Mali, Niger and Senegal)

with its three concentric zones there was either: a single corresponding control plot away from any of the surrounding trees for fields $<1$ ha; or four control plots in each $25 \mathrm{~m}$ by $25 \mathrm{~m}$ quadrant of the $100 \mathrm{~m} \times 100 \mathrm{~m}$ main plot. For each concentric zone (T1, T2, T3) and control plot (s) (T0), soil was sampled at two randomly determined positions. At each position four different depths were sampled
(0-10, 10-30, 30-50 and 50-70 cm corresponding to D1, D2, D3 and D4, respectively). Soil samples of the two positions for each zone (T1, T2, and T3) were mixed for each depth to have one composite sample for that depth, giving a total of 12 soil samples for each sampled tree. For fields $>1$ ha, the composite samples of the control (T0) per quadrat (with four samples at four sampling points giving 16 samples) were further mixed according to the procedure described above to give a single composite sample for that given field for each soil depth, or 4 samples in total. At the end of this process, regardless of its size, each field had four samples per concentric zone and 16 samples in total. There were a few cases where a hardpan did not allow sampling beyond certain depths. Soil samples were air dried under shade and shipped to the soil laboratory of the World Agroforestry Centre (ICRAF) in Nairobi (Kenya) to be measured using a Near Infrared (NIR) spectroscopy method (TerhoevenUrselmans et al. 2010) after crushing and sieving them using $2 \mathrm{~mm}$ sieve.

Twenty percent of the samples were analyzed using the Standard Operating Procedures (SOPs) of the SoilPlant Spectral Diagnostics Laboratory of ICRAF (http://www.worldagroforestry.org/sd/landhealth/soilplant-spectral-diagnostics-laboratory/sops). These results were used to calibrate the results of the NIR. Out of the measured elements only sand, total $\mathrm{C}$ and ExBas (Ca, $\mathrm{Mg}, \mathrm{K}$, and $\mathrm{Na}$ ) were used in the analyses presented because they had sufficient precision of estimation (calibration error of 4\%), based on the calibration and were not closely correlated with other parameters.

Data analysis

Given the complexity of disentangling the effects of tree regeneration stages or categories from other effects, data were explored using a range of approaches and tools. We investigated the patterns of soil properties around and away from trees with reference to sand content because we expect this to be a property that is not changed by management but is a relatively fixed characteristic of each sampling point. To look at overall patterns, means of sand, total $\mathrm{C}$ and ExBas were plotted for different zones and soil depths (Fig. 3). This graphical method provides a visual means to compare the observed distribution of response variables against competing hypotheses: 

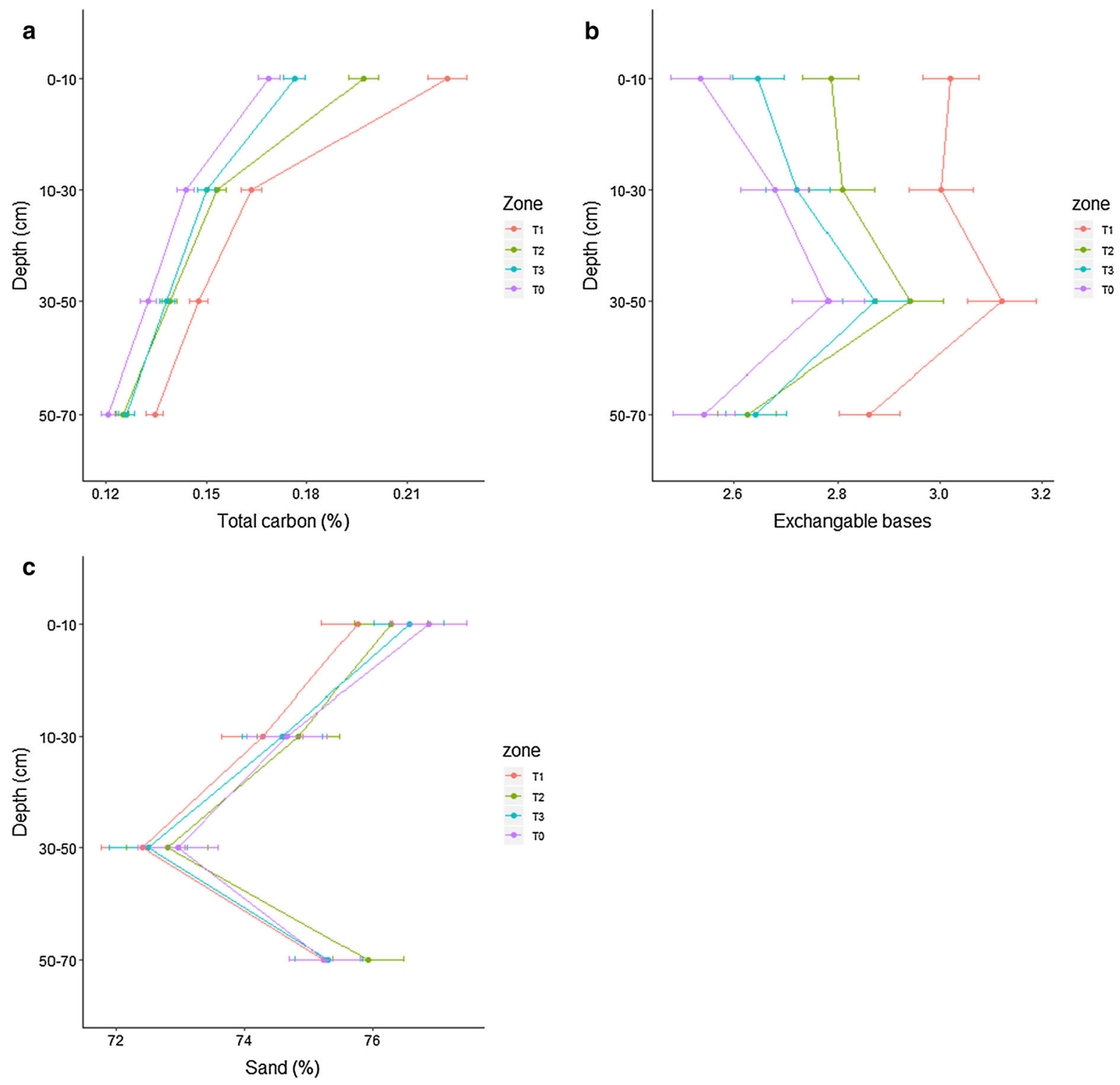

Fig. 3 Mean values of a total carbon (\%), b exchangeable bases $\left(\mathrm{cmol}_{\mathrm{c}} \mathrm{kg}^{-1}\right)$ and $\mathbf{c}$ sand (\%) for different distance to a tree trunk (T1: 0-half radius, T2: half-radius to edge of crown, T3: from crown edge to $3 \mathrm{~m}$ away and T0: away from the tree) and soil

H0 No consistent effects of sample location with random and symmetrical scatter around the 1:1 line soil under the canopy is equal to that in the open area (null hypothesis);

H1 Effects of tree regeneration in each category are consistently positive across all site soil conditions;

H2 Effects of tree regeneration are, in absolute sense, more positive on sites with low values for the

depth $(0-10 \mathrm{~cm}, 10-30 \mathrm{~cm}, 30-50 \mathrm{~cm}$ and $50-70 \mathrm{~cm})$ of different tree regeneration stage plots in four Sahelian countries (Burkina Faso, Mali, Niger and Senegal). Error bars are mean \pm standard error

considered variable than on sites with high values (Fig. 4);

H3 Effects of tree regeneration category are more positive on sites with high values for the considered variable than on sites with low values (Fig. 4).

Measured values for the three depth intervals D1, D2 and D3 were strongly correlated, so the mean of soil properties in each zone relative to that in $\mathrm{T} 0$ across 


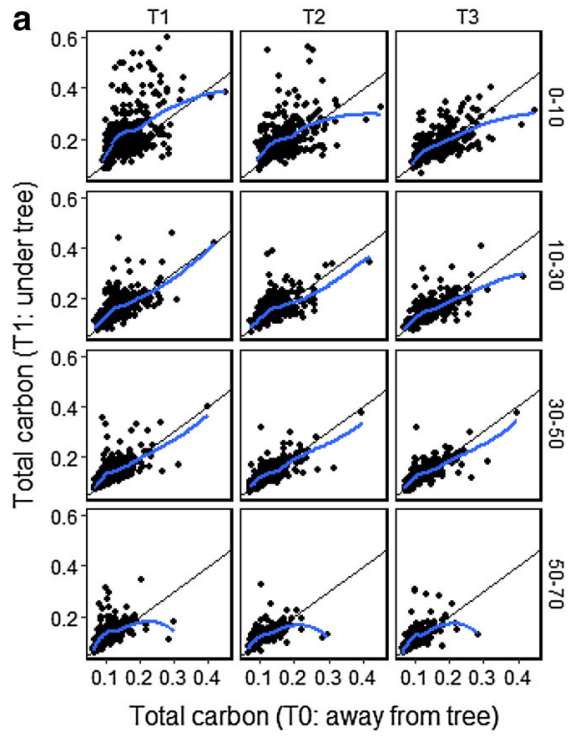

Fig. 4 a Total $\mathrm{C}(\%)$, b exchangeable bases $\left(\mathrm{cmol}_{\mathrm{c}} \mathrm{kg}^{-1}\right)$ and under tree influence zone according to distance from tree trunk (T1: 0-half radius, $\mathrm{t} 2$ : half-radius to edge of crown and $\mathrm{T} 3$ : from crown edge to $3 \mathrm{~m}$ away) plotted against the value in the corresponding sample away from trees (T0) for four soil depth

these three soil layers was used for further exploration of the variation in tree effect by environment. The sites were then divided into four groups according to their average sand content in the control (50-60, 60-70, 70-80 and 80-100\%). To complement the inferences from the graphic methods described above, an analysis of variance was performed using the following factors: sandclass, species, tree regeneration stage and their two-way as well as three-way interactions. Statistical analyses were performed with GenStat Release 12.2 (Rothamsted Experimental Station, PC/Windows Vista).

\section{Results}

Overall patterns of total $\mathrm{C}$ and ExBas

Averaged across all sampled trees, total $\mathrm{C}$ decreased with soil depth and distance from tree trunk (Fig. 3a). Thus, the lowest $\mathrm{C}$ values were recorded at deepest soil layer and away from trees (T0) whereas the upper soil layer and the zone immediately around the tree trunk (T1) displayed the highest values. The values of T2-T3 and 10-50 cm depth were intermediate (Fig. 3a). A similar trend was observed for the

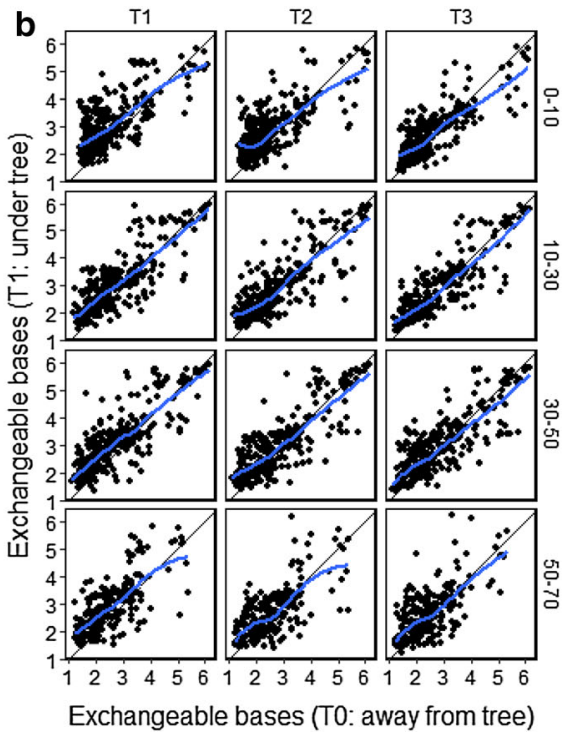

$(0-10 \mathrm{~cm}, \quad 10-30 \mathrm{~cm}, \quad 30-50 \mathrm{~cm}$ and $50-70 \mathrm{~cm})$ of tree regeneration stage plots in four Sahelian countries (Burkina Faso, Mali, Niger and Senegal). The black line is the 1:1 line. The blue line is a smooth curve showing conditional means (Colour figure online)

Fig. 5 Soil status away from trees in fields with different levels of tree regeneration (low, new and high) in four Sahelian countries (Burkina Faso, Mali, Niger and Senegal). a Average sand content $(\%)$, b Topsoil $(0-10 \mathrm{~cm})$ total carbon $(\%)$, c Topsoil (0-10 cm) exchangeable bases $\left(\mathrm{cmol}_{\mathrm{c}} \mathrm{kg}^{-1}\right)$, d Topsoil carbon $\mathrm{v}$ average sand content, e Topsoil exchangeable bases versus average sand content. Lines are a smooth curves showing conditional means

exchangeable bases with highest values under the tree and lowest away from the tree. On average there are increasing exchangeable bases down the profile then an abrupt decrease between depths 30-50 and 50-70 cm (Fig. 3b). In contrast, there was no significant difference in sand content between sampling points (Fig. 3c).

There was considerable variation between sample locations (T1, T2, T3 and T0) in the differences in soil properties under and away from trees. We investigated this first by plotting the values under trees (zone T1, $\mathrm{T} 2$ and T3) against the corresponding value away from the tree (T0) (Fig. 4). If there were no difference in soils under and away from trees the points would lie on the 1:1 line. For carbon, the differences are most prominent in topsoil $(0-10 \mathrm{~cm})$ under the trees $(\mathrm{T} 1)$. The average difference from $\mathrm{T} 0$ was zero at the lowest 

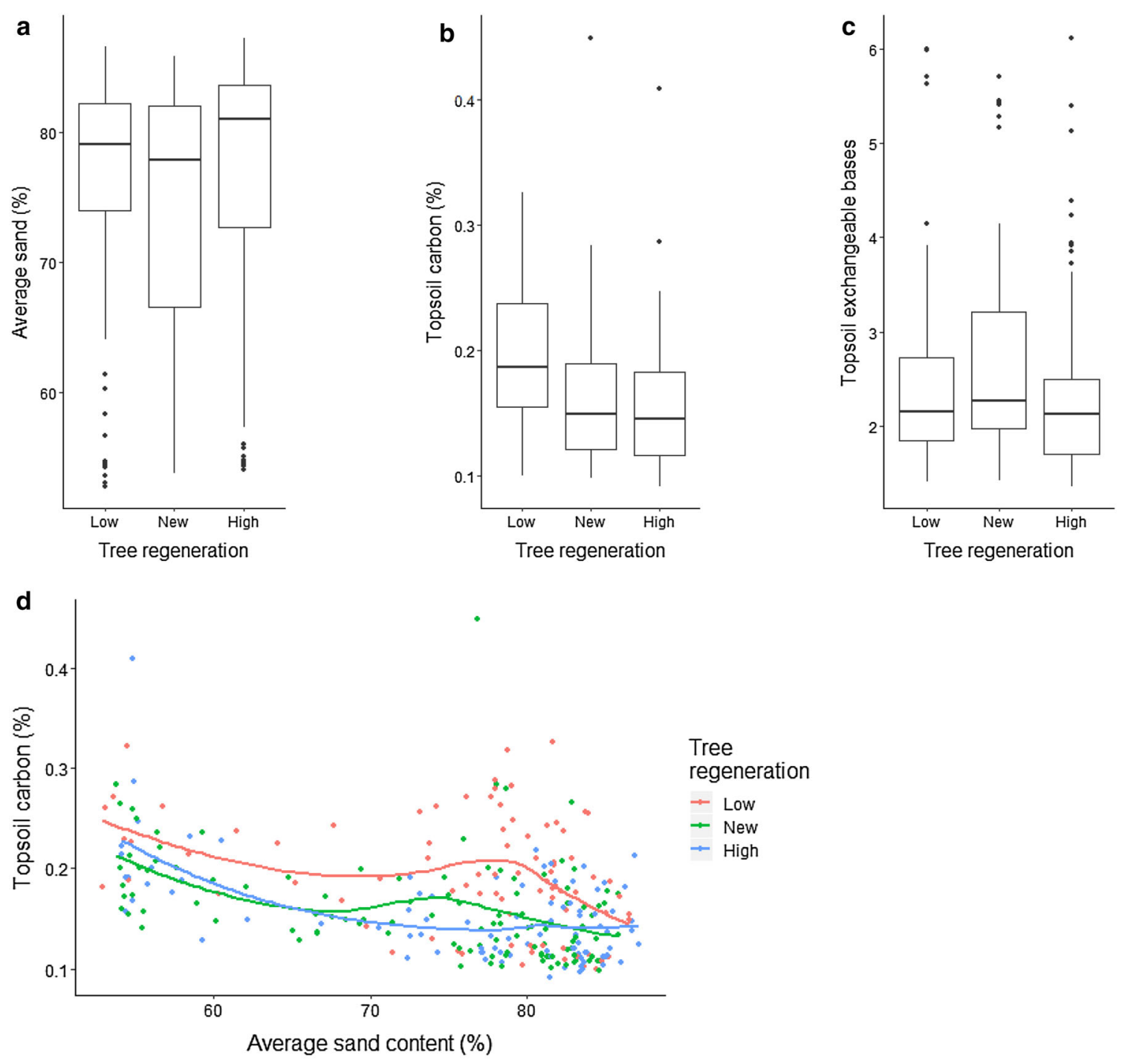

Tree

regeneration
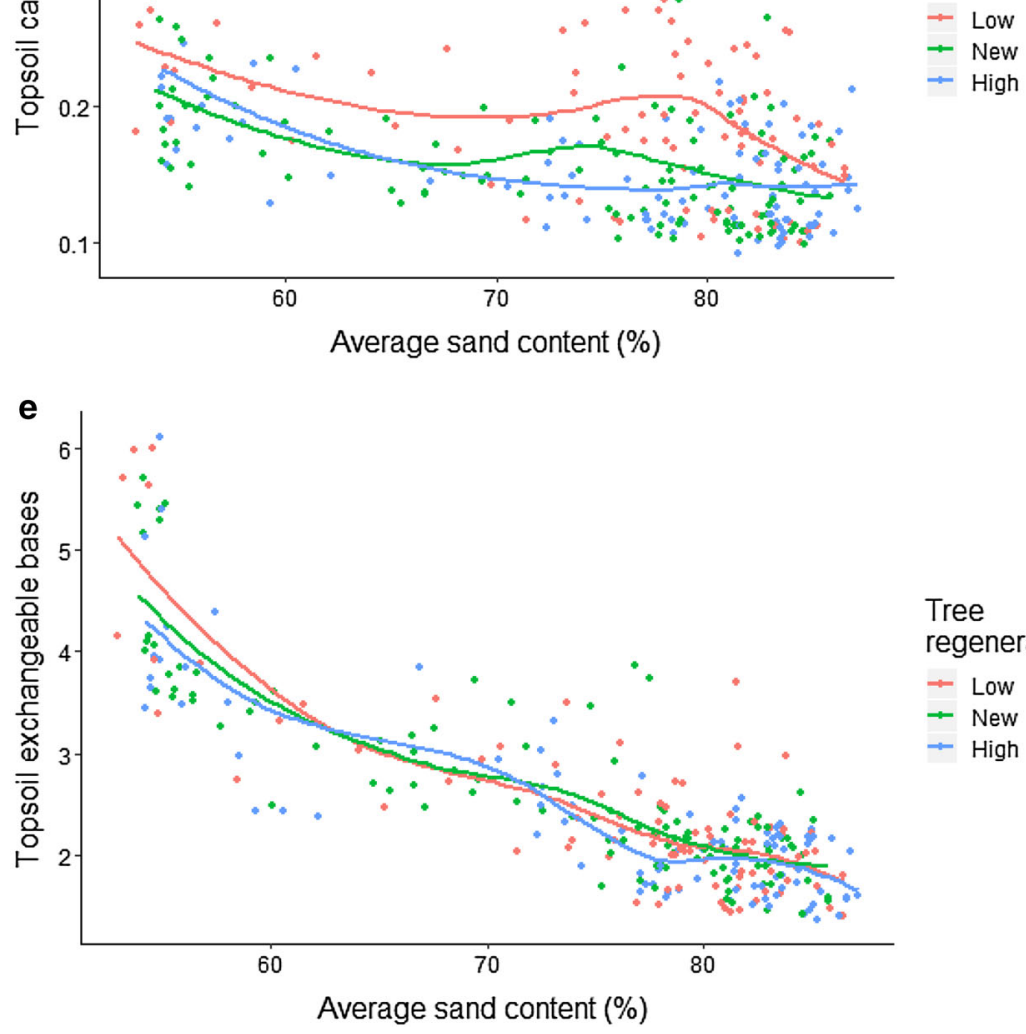

Tree

regeneration

- Low
- New
- High 
C content $(0.1 \%)$, highest at low values of $0.15 \%$ and then decreased for higher levels of carbon in T0. The maximum average effect was when topsoil $\mathrm{C}$ away from and under the tree was $0.15 \%$ and $0.25 \%$. respectively. The pattern was slightly different for exchangeable bases in that the differences were seen at all levels down the profile, and the largest effect (increase from 1.0 to $2.3 \mathrm{cmol}_{\mathrm{c} \mathrm{kg}} \mathrm{kg}^{-1}$ ) occurred in soils with the lowest levels of exchangeable bases in T0. The most striking feature on Fig. $4 a, b$ is the high variation around the means. While at some locations the difference between under and away from trees is large, at others there is no apparent effect. Hence we looked for factors associated with this wide variation.

\section{Occurrence of patterns of tree regeneration}

The samples away from trees (T0) probably indicated the status of soils with minimal tree effects. There were no overall differences in content of topsoil sand and exchangeable bases away from trees between fields with different levels of tree cover (Fig. 5a, c). However there was a clear difference in the topsoil total C. Sites with low tree cover tended to have higher levels of topsoil C away from trees (Fig. 5b). Both topsoil $\mathrm{C}$ and exchangeable bases away from trees were related to the sand content (Fig. $5 \mathrm{~d}$, e). The tendency for higher $\mathrm{C}$ away from trees in fields with low tree cover applied across the full range of sand contents, from 50 to $90 \%$ sand (Fig. 5d). This might imply that farmers choose to keep tree density low on more fertile soils, where soil $\mathrm{C}$ is relatively high for that particular sand content. Conversely, farmers appeared to keep or allow newly regenerating trees in sites that have low soil $\mathrm{C}$ relative to the sand content. This suggests that choices between tree cover classes are, among other things, a response to the site and not only a response to outside influences promoting FMNR.

\section{Differences in species niches}

Five of the fourteen dominant species (Azadirachta indica, Detarium microcarpum, Neocaria macrophylla, Tamarindus indica and Ziziphus mauritiana) occurred in only one or two samples each so there was little information about them (Table 1). Some species tended be found more in sites of one tree cover class than another $(p<0.001)$. Sites with low tree cover are most often dominated by Faidherbia albida. The same is true for sites with high tree cover where Combretum micranthum is also found disproportionally often. Fields with new tree cover tended to be dominated by Balanites aegyptiaca or Piliostigma reticulatum (Table 1).

Figure 6 shows the distribution of sand content of sites dominated by different species, revealing distinct niches for many of them. For example Acacia seyal

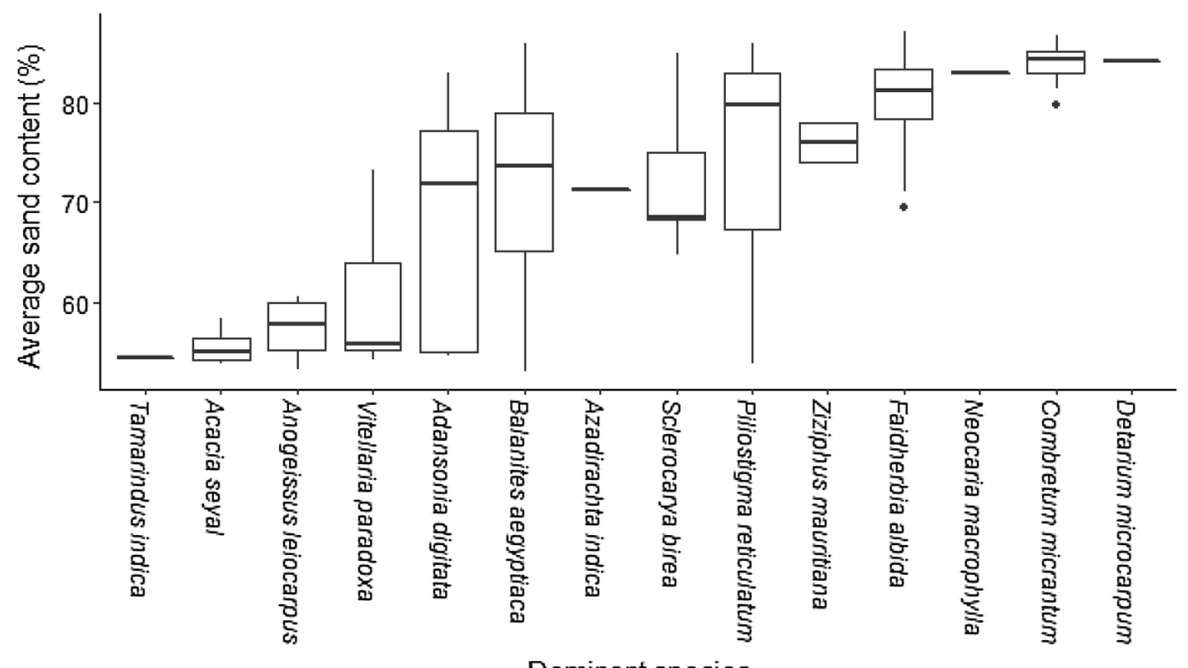

Fig. 6 Distribution of sand content away from trees in areas dominated by different species in tree regeneration stage plots in four Sahelian countries (Burkina Faso, Mali, Niger and Senegal) 
and Anogeissus leiocarpus were only found on the least sandy sites (in line with their known preference for clayey soils and wet locations). Faidherbia albida and Combretum micranthum were found only on the most sandy sites. Adansonia digitata, B. aegyptiaca and $P$. reticulatum occurred more widely than other species.

Variation in tree effects

For sand content between 80 and $90 \%$ the average difference in carbon content was highest for low tree regeneration, with a mean increment of $0.15 \%$, an increase of about $50 \%$ over the baseline. A similar pattern was found in the level of exchangeable bases with the average difference between under and away from trees being very low for soils with lower sand content. It was about $0.8 \mathrm{cmol}_{\mathrm{c}} \mathrm{kg}^{-1}$ for soils of $80-90 \%$ sand, an increase of $40 \%$ over baseline.

Tree species apparently influenced the difference in topsoil carbon under and away them (Fig. 7a), with the common species Combretum micranthum, Piliostigma reticulatum and Faidherbia albida consistently showing a higher carbon content under trees than away. Tree species had less clear effects on the differences in exchangeable bases (Fig. 7b).

The factors associated with differences in topsoil properties under and away from trees-sand content, tree species and regeneration stage, were investigated.
Fig. 7 Differences in a top soil carbon $(\%)$ and b exchangeable bases $\left(\mathrm{cmol}_{\mathrm{c}} \mathrm{kg}^{-1}\right)$ between measurements under the tree (T1) and away from trees (T0) for different dominant tree species in four Sahelian countries (Burkina Faso, Mali, Niger and Senegal)

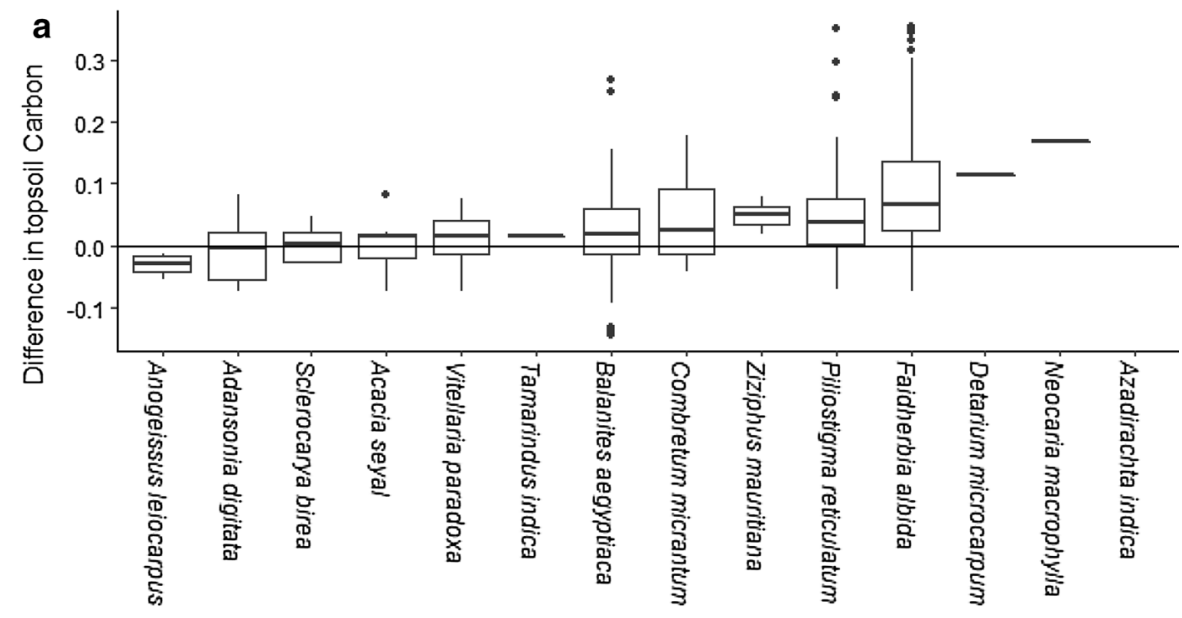

Dominant species

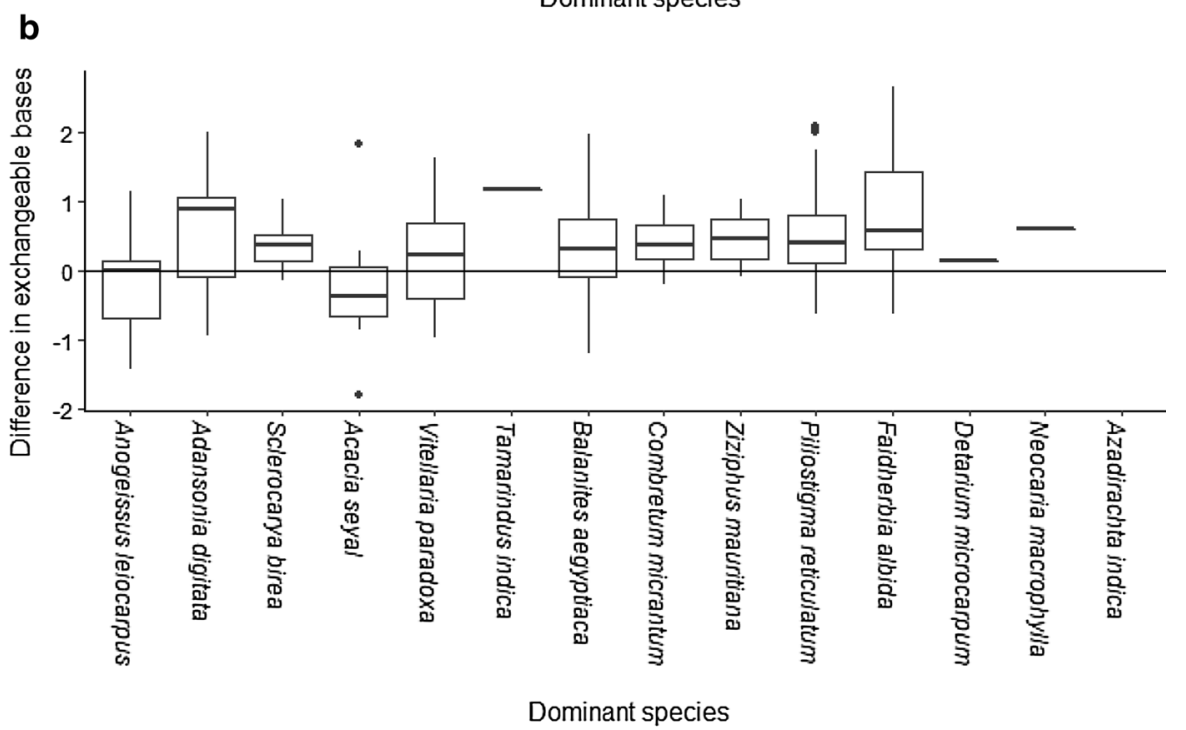


Table 2 Analysis of variance of contribution of sand content (classified as $<60 \%, 60-70 \%, 70-80 \%,>80 \%$ ), dominant tree species and level of tree regeneration to (a) differences in topsoil total C (\%) under and away from trees and

\begin{tabular}{|c|c|c|c|c|c|c|c|}
\hline \multirow[t]{2}{*}{ Source } & \multirow[t]{2}{*}{$d f$} & \multicolumn{3}{|c|}{ (a) Carbon } & \multicolumn{3}{|c|}{ (b) Exchangeable bases } \\
\hline & & Mean Sq & $\mathrm{F}$ & $p$ & Mean Sq & $\mathrm{F}$ & $p$ \\
\hline Sand & 3 & 0.0918 & 13.8 & $0.000 * * *$ & 5.553 & 12.7 & $0.000 * * *$ \\
\hline Species & 12 & 0.0129 & 1.9 & $0.031 *$ & 0.646 & 1.5 & 0.132 \\
\hline Regeneration & 2 & 0.0242 & 3.6 & $0.028 *$ & 1.164 & 2.7 & 0.072 \\
\hline Sand:species & 13 & 0.0029 & 0.4 & 0.958 & 0.666 & 1.5 & 0.109 \\
\hline Sand:regeneration & 6 & 0.0097 & 1.4 & 0.197 & 0.882 & 2.0 & 0.064 \\
\hline Species:regeneration & 16 & 0.0027 & 0.4 & 0.981 & 0.573 & 1.3 & 0.190 \\
\hline Sand:species:regeneration & 8 & 0.0020 & 0.3 & 0.965 & 0.143 & 0.3 & 0.955 \\
\hline Residuals & 225 & 0.0067 & & & 0.436 & & \\
\hline
\end{tabular}

Asterisks represents the level of significance of the statistical analysis as follows: $* p<0.05 ; * * p<0.01 ; * * * p<0.001$

Simultaneously fitting linear models and using analysis of variance revealed clear and statistically significant $(p<0.05)$ effects of sand content, species and levels of regeneration on total carbon and no important interactions between these (Table 2). However, there was a confounding effect between species and sand:regeneration interaction. The species differences identified could equally be attributed to an interaction effect, noticeable in Fig. 8a, with larger differences in $\mathrm{C}$ for low tree regeneration when the sand content is high.

The nature of the significant effects on topsoil total $\mathrm{C}$ are shown by predicted means (Table 3 ) for each factor. These confirm that the difference in $\mathrm{C}$ content between under and away from trees increased with sand content and was clearly positive for sand content $>70 \%$. Thus the individual trees produce 'hotspots' of topsoil $\mathrm{C}$ in the sandiest soils, but not in less sandy soils. The hotspot feature is confirmed for $F$. albida, B. aegyptica and $P$. reticulatum. The upper confidence limit is positive for all species, and in many cases higher than the value for these three, suggesting that they might also have a positive effect but the small sample sizes and level of unexplained variation mean that we cannot reach a firm conclusion about them. The average difference in each regeneration stage is positive with the largest effect for low regeneration. When there are few trees in the landscape the difference in topsoil $\mathrm{C}$ under and away from those trees is larger than when there are many trees, whether these are old or newly established. This could be (b) differences in topsoil exchangeable bases under and away from trees in four Sahelian countries (Burkina Faso, Mali, Niger and Senegal) 
Fig. 8 Differences in a top soil carbon $(\%)$ and b exchangeable bases $\left(\mathrm{cmol}_{\mathrm{c}} \mathrm{kg}^{-1}\right)$ between measurements under the tree (T1) and away from trees (T0) plotted against average sand content $(\%)$ away from the trees for three patterns of tree regeneration in four Sahelian countries (Burkina Faso, Mali, Niger and Senegal). Lines are smooth curves showing conditional means
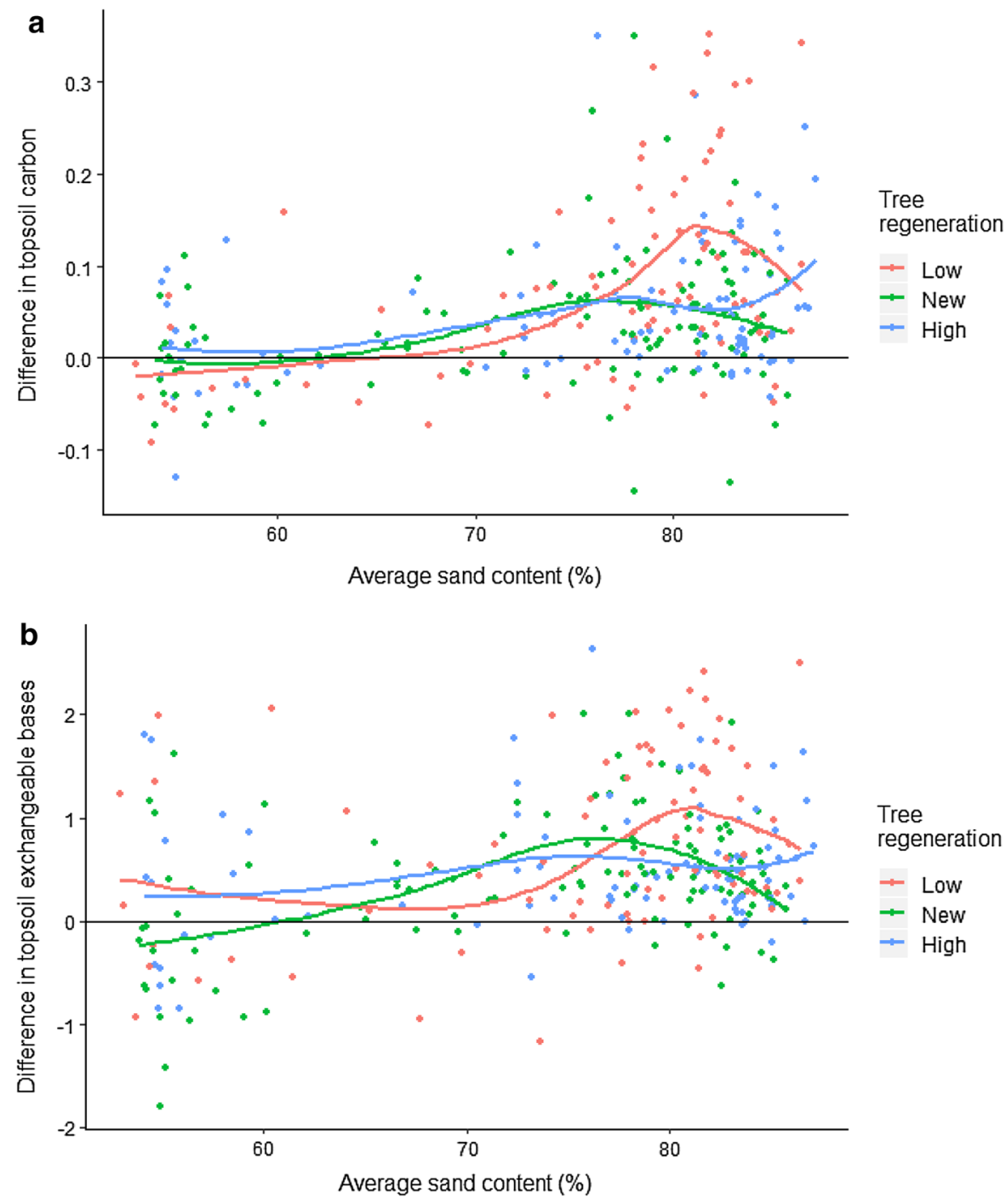

practicing regeneration at different intensity levels (Binam et al. 2015; Savadogo et al. 2015).

Basing our assessment on total carbon (Ontl and Schulte 2012) which comprises organic carbon (bacteria and fungi, decaying material from once-living organisms such as plant and animal tissues, fecal material, and products formed from their decomposition) and inorganic (carbonate, bicarbonate salts and minerals) was a difficult decision. Yet, opting for total carbon was a compromise to be able to analyze large number of samples (4471 in total for the 4 countries) with the NIR at cheapest cost (Terhoeven-Urselmans et al. 2010). This is because we think that our assumption that inorganic carbon content, which is mainly from soil parent materials, doesn't significantly vary within the short distance between the plots (concentric zones) under tree and control for each individual tree holds.

Various patterns of soil fertility changes induced by trees can be hypothesized and only some of these can be distinguished (Fig. 9). For each of these there are possible mechanisms, with $\mathrm{A}$ and $\mathrm{B}$ representing addition to the soil resource and $\mathrm{C}$ representing redistribution. Much the same pictures can be drawn whether we consider comparable locations with and without trees or consider the difference between before and after tree establishment and growth. We have measured $\mathrm{S}$ at positions $\mathrm{T} 1, \mathrm{~T} 2, \mathrm{~T} 3$ and $\mathrm{T} 0$, giving observations $\mathrm{S} 0, \mathrm{~S} 1, \mathrm{~S} 2$ and $\mathrm{S} 3$ with no independent measurement equivalent to situation $\mathrm{O}$. 
Table 3 Predicted (adjusted) mean differences in topsoil total $\mathrm{C}(\%)$ under and away from trees for different levels of sand, dominant tree species and tree regeneration categories $(\mathrm{SE}=$ standard error of mean, confidence intervals at $95 \%, *$ mean difference significantly $(p<0.05)$ different from zero) in four Sahelian countries (Burkina Faso, Mali, Niger and Senegal)

\begin{tabular}{|c|c|c|c|c|c|}
\hline \multirow[t]{2}{*}{ Factor } & \multirow[t]{2}{*}{ Levels } & \multirow[t]{2}{*}{ Predicted mean } & \multirow[t]{2}{*}{ SE } & \multicolumn{2}{|c|}{ Confidence interval } \\
\hline & & & & Lower & Upper \\
\hline \multirow[t]{4}{*}{ Sand } & $50-60$ & 0.009 & 0.017 & -0.023 & 0.042 \\
\hline & $60-70$ & 0.031 & 0.020 & -0.009 & 0.071 \\
\hline & $70-80$ & 0.058 & 0.015 & 0.027 & $0.088^{*}$ \\
\hline & $>80$ & 0.070 & 0.015 & 0.041 & $0.100 *$ \\
\hline \multirow[t]{13}{*}{ Species } & Acacia seyal & 0.042 & 0.032 & -0.021 & 0.105 \\
\hline & Adansonia digitata & -0.014 & 0.026 & -0.066 & 0.038 \\
\hline & Anogeissus leiocarpus & -0.003 & 0.036 & -0.074 & 0.068 \\
\hline & Balanites aegyptiaca & 0.025 & 0.011 & 0.004 & $0.047 *$ \\
\hline & Combretum micrantum & 0.020 & 0.019 & -0.017 & 0.058 \\
\hline & Detarium microcarpum & 0.096 & 0.079 & -0.060 & 0.252 \\
\hline & Faidherbia albida & 0.068 & 0.011 & 0.047 & $0.089 *$ \\
\hline & Neocaria macrophylla & 0.119 & 0.079 & -0.037 & 0.276 \\
\hline & Piliostigma reticulatum & 0.043 & 0.010 & 0.023 & $0.062 *$ \\
\hline & Sclerocarya birea & 0.003 & 0.033 & -0.061 & 0.067 \\
\hline & Tamarindus indica & 0.060 & 0.080 & -0.097 & 0.217 \\
\hline & Vitellaria paradoxa & 0.044 & 0.034 & -0.022 & 0.111 \\
\hline & Ziziphus mauritiana & 0.043 & 0.056 & -0.068 & 0.154 \\
\hline \multirow[t]{3}{*}{ Tree regeneration } & Low & 0.062 & 0.015 & 0.032 & $0.092 *$ \\
\hline & New & 0.030 & 0.014 & 0.003 & $0.058^{*}$ \\
\hline & High & 0.034 & 0.015 & 0.004 & 0.064 \\
\hline
\end{tabular}

Hence interpretation of $\mathrm{Si}$ and the differences $\mathrm{Si}-\mathrm{S} 0$ depend on which of $\mathrm{A}, \mathrm{B}, \mathrm{C}$ or $\mathrm{D}$ is occurring. If we find a consistent positive difference $\mathrm{Si}-\mathrm{S} 0$ then A might be operating but trees occur in spots that have a prior difference. If case $\mathrm{C}$ is operating then the differences $\mathrm{Si}-\mathrm{S} 0$ do not present the change from the baseline with no trees, case 0 . Hence, if $\mathrm{S} 1-\mathrm{S} 0$ is large then $\mathrm{B}$ or $\mathrm{C}$ is likely though $\mathrm{A}$ with $\mathrm{V}$ is possible and other explanations might be consistent with the data.

\section{Spatial patterns}

The two soil properties for which we observed trends associated with the presence of trees [total $\mathrm{C}$ and ExBas (Ca, Mg, K, Na)] may represent different mechanisms for tree effects. For total $\mathrm{C}$ differential effects at increasing horizontal distance away from trees may represent differences in root turnover and/or aboveground organic inputs, partially compensated (or enhanced) by changes in crops, weeds or grasses with distance from the tree. For the ExBas parameter active removal away from the tree (but within reach of tree roots) and return in throughfall or litter recycling under the tree could have increased the contrast, without necessarily indicating a field-level increase. A net increase in exchangeable bases at field level may, in the absence of fertilizer use, depend primarily on atmospheric deposition, transfer from beyond field boundaries by cattle (or other herbivores and birds) resting under (or in) the trees. Previous research showed that the decay of tree influence with distance depends on the soil parameter considered (Belsky et al. 1989; Sileshi 2016). The vertical decrease in effects on cation contents with soil depth that we observed is consistent with trees taking up nutrients down the soil profile but re-cycling predominantly in surface soil through leaf litter and fine root turnover (Pinho et al. 2012). As the decomposition forms negatively charged particles that retain cations such as $\mathrm{Ca}, \mathrm{Mg}, \mathrm{K}$, and $\mathrm{Na}$ on the surface (Pinho et al. 2012), their abrupt decrease from $30 \mathrm{~cm}$ depth (Fig. 3b) might be a result of higher uptake from these layers. Other potential sources of soil fertility improvement are faeces of birds and livestock and deposition of organic dust but these sources are likely to be negligible (Bayala et al. 2006). 


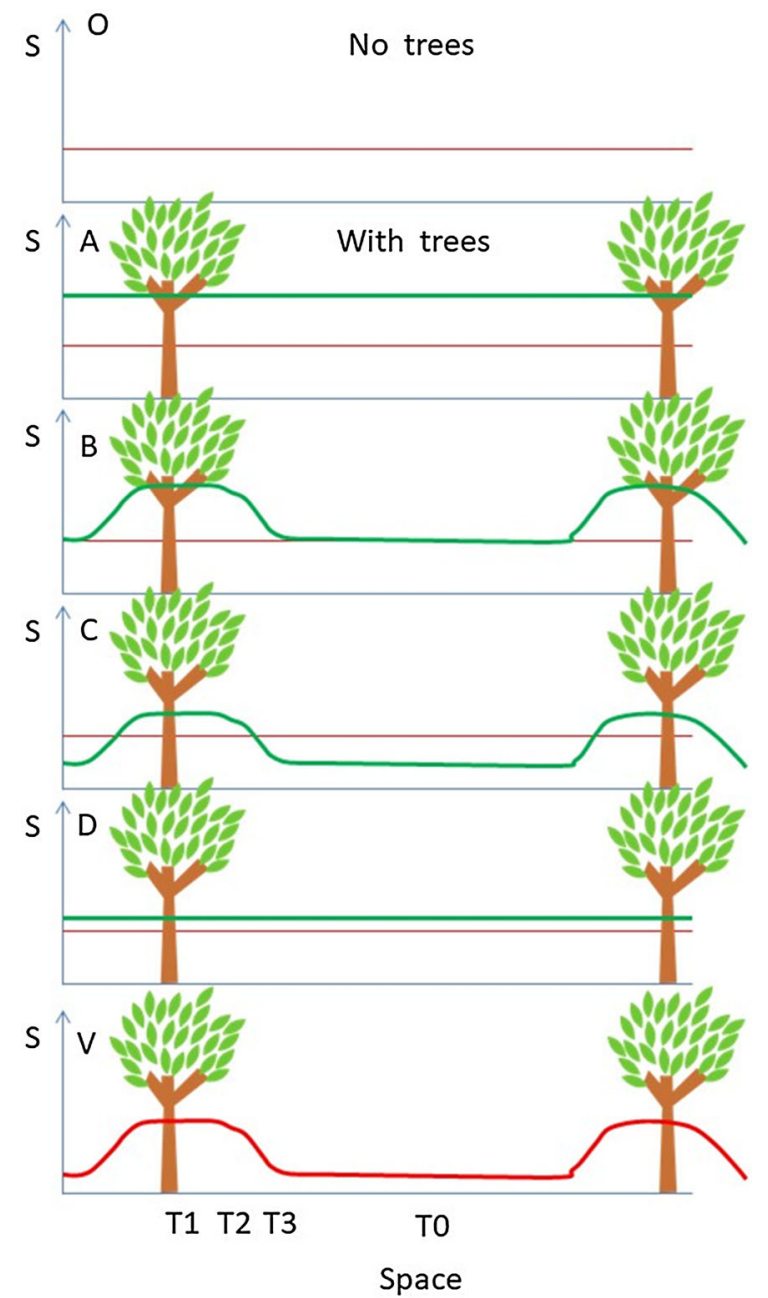

Fig. 9 Possible effects of trees on soil properties in parklands. $S$ represents any soil property of interest (e.g. soil carbon or exchangeable bases) with the positive direction being 'better'. The horizontal axis represents the space or distance within a parkland location. O represents the situation without trees; A. There is an overall increase relative to 'without trees', but no 'patch' around the trees; B. There is an increase under or close to trees but no change away from trees; C. There is an increase under or close to trees and a decrease away from trees; D. There is no effect of trees on $\mathrm{S}$; V. Trees occur in pre-existing high fertility spots

The effects of trees were found to be more positive on sites with low soil total $\mathrm{C}$ and exchangeable bases away from the tree and high sand content, agreeing with previous workers (Bayala et al. 2012; Sileshi 2016). This is consistent with high $C$ content where trees were less intensively regenerated indicating that farmers promote tree regeneration on poor soils at least partly because of their ability to restore soil fertility, which goes beyond simply redistributing nutrients to embrace soil health. This supports previous observations (Bayala et al. 2006, 2018; Sileshi 2016) and is also consistent with higher yield increases associated with trees on poor soils and in low rainfall areas (Bayala et al. 2012; Sileshi et al. 2008). Along the same lines, fields with a high density of trees of mixed ages were expected to display larger soil $\mathrm{C}$ accumulation compared to fields with only young ones. The difference between these is not significant (Table 3) potentially because of two none mutually exclusive reasons. The first is sampling under one individual of the dominant species and the composite nature of our samples. The second reason is related to the difficulty in categorizing the fields vis-à-vis tree regeneration patterns when the baseline of the concerned activity is unknown (Binam et al. 2015).

The proportional increase between under and away from trees is high for the most sandy soils, at up to $46 \%$ a similar magnitude to that reported for $F$. albida by Sileshi (2016). This is within the range of 25-46\% reported in a review of parkland effects on soil carbon content in Sub-Saharan Africa (Bayala et al. 2018). The difference between under and away is associated with that of the balance between inputs (organic matter) and outputs (soil respiration). This is due to the higher biomass accumulated (litter and roots), the microclimate, the higher soil moisture and species itself, all known to influence $\mathrm{CO}_{2}$ efflux (VillanuevaLópez et al. 2014; Yohannes et al. 2011).

\section{Conclusion}

This study of nearly 300 parkland fields in four countries confirms that soil fertility, as indicated by soil total carbon and exchangeable bases, is enhanced under trees. This pattern can be seen in sites with recent (high density of young trees) increases in tree cover due to changes in the way farmers are managing natural regeneration as well as in sites with few old trees. The absolute differences between soils under and away from tree are modest but large enough to be an important contribution to soil restoration and fertility management in these areas of low inherent fertility and high rates of degradation. There is important variation in where trees are regenerating and the species that are regenerating. Farmers maintain low tree densities where soils are comparatively 
fertile and but have either recently or over a longer time period allowed regeneration in less fertile soils. The species that occur in managed regeneration depend on the site and have differing impacts on soils. Soil texture is an important determinant of the impact of trees on soils. Our results showed that when sand content was around 50\% trees did not help increase soil carbon but in soils with a high sand content over $80 \%$, trees can provide the continuous supply of organic inputs needed to maintain soil carbon. We still know little about the landscape level effects on soils of changing patterns of tree cover in parklands making this a continuing priority for further research.

Acknowledgements The research was funded as part of Greening the Sahel, building an evidence base (EGAT/GCC), USAID Number: EEM-G-00-04-00010-00 associated with the Livelihood Systems flagship of the CGIAR research program on Forests, Trees and Agroforestry. Participation of RC and FS was funded by IFAD/EU-funded Dryland Restoration project.

Open Access This article is distributed under the terms of the Creative Commons Attribution 4.0 International License (http:// creativecommons.org/licenses/by/4.0/), which permits unrestricted use, distribution, and reproduction in any medium, provided you give appropriate credit to the original author(s) and the source, provide a link to the Creative Commons license, and indicate if changes were made.

\section{References}

Ahlström A, Raupach MR, Schurgers G et al (2015) The dominant role of semi-arid ecosystems in the trend and variability of the land $\mathrm{CO}_{2}$ sink. Science 348:895-899

Aryal DR, Gómez-González RR, Hernández-Nuriasmú R, Morales-Ruiz DE (2019) Carbon stocks and tree diversity in scattered tree silvopastoral systems in Chiapas, Mexico. Agrofor Syst 93:213-227

Bationo A, Kihara J, Vanlauwe B, Waswa B, Kimetu J (2007) Soil organic carbon dynamics, functions and management in West African agro-ecosystems. Agric Sys 94(1):13-25

Bayala J, Balesdent J, Marol C, Zapata F, Teklehaimanot Z, Ouedraogo SJ (2006) Relative contribution of trees and crops to soil carbon content in a parkland system in Burkina Faso using variations in natural $13 \mathrm{C}$ abundance. Nutr Cycl Agroecosyst 76:193-201

Bayala J, Sileshi GW, Coe R, Kalinganire A, Tchoundjeu Z, Sinclair F, Garrity D (2012) Cereal yield response to conservation agriculture practices in drylands of West Africa: a quantitative synthesis. J Arid Environ 78:13-25

Bayala J, Kalinganire A, Sileshi GW, Tondoh JE (2018) Soil organic carbon and nitrogen in agroforestry systems in Sub-Saharan Africa: a review. In: Bationo A, Ngaradoum
D, Youl S, Lompo F, Opoku Fening J (eds) Improving the profitability, sustainability and efficiency of nutrients through site specific fertilizer recommendations in West Africa Agro-Ecosystems. Springer International Publishing AG, pp 51-61

Belsky AJ, Amundson RG, Dixbury M, Riha SL, Au AR, Mwonga SM (1989) The effects of trees on their physical, chemical, and biological environments in a semi-arid savanna in Kenya. J Appl Ecol 26:1005-1024

Binam JN, Place F, Kalinganire A et al (2015) Effects of farmer managed natural regeneration on livelihoods in semi-arid West Africa. Environ Econ Policy Stud 17(4):543-575

Coe R, Njoloma J, Sinclair F (2017) To control or not to control: How do we learn more about how agronomic innovations perform on farms? Expl Agric. https://doi.org/10.1017/ s0014479717000102

Doetterl S, Kearsley E, Bauters M et al (2016) Aboveground vs. belowground carbon stocks in African tropical lowland rainforest: drivers and implications. PLoS ONE 11(2): 0150681

Foster D, Swanson F, Aber J, Burke I, Brokaw N, Tilman D, Knapp A (2003) The importance of land-use legacies to ecology and conservation. Bioscience 53(1):77-88

Gibbs HK, Ruesch AS, Achard F, Clayton MK, Holmgren P, Ramankutty N, Foley JA (2010) Tropical forests were the primary sources of new agricultural land in the 1980s and 1990s. PNAS 107(38):16732-16737

Green J, Larrosa C, Burgess ND, Balmford A, Johnston A, Mbilinyi BP, Platts P, Coad L (2013) Deforestation in an African biodiversity hotspot: extent, variation and the effectiveness of protected areas. Biol Conserv 164:62-72

Keesstra SD, Bouma J, Wallinga J et al (2016) The significance of soils and soil science towards realization of the United Nations Sustainable Development Goals. Soil 2:111-128

Lal R (2004) Soil carbon sequestration impacts on global climate change and food security. Science 304:1623-1627

Lorenz K, Lal R (2014) Soil organic carbon sequestration in agroforestry systems. A review. Agron Sustain Dev 34:443-454

Mathayo MM, Majule AE, Sinclair F, Marchant R (2016) Relationships between on-farm tree stocks and soil organic carbon along an altitudinal gradient, Mount Kilimanjaro, Tanzania. For Trees Livelihoods 25(4):255-266

McCormack ML, Dickie IA, Eissenstat DM et al (2015) Redefining fine roots improves understanding of belowground contributions to terrestrial biosphere processes. New Phytol 207(3):505-518

Minasny B, Malone BP, McBratney AB et al (2017) Soil carbon 4 per mille. Geoderma 292:59-86

Ontl TA, Schulte LA (2012) Soil carbon storage. Nat Educ Knowl 3(10):35

Pinho RC, Miller RP, Sonia S, Alfaia SS (2012) Agroforestry and the improvement of soil fertility: a view from Amazonia. Appl Environ Soil Sci 2012, 616383. https://doi.org/ 10.1155/2012/616383

Poulter B, Frank D, Ciais P et al (2014) Contribution of semiarid ecosystems to interannual variability of the global carbon cycle. Nature 509:600-603

Sanderman J, Hengl T, Fiske GJ (2017) Soil carbon debt of 12,000 years of human land use. PNAS 114(36):9575-9580 
Savadogo MO, Ouattara K, Barron J, Ouedraogo I, Gordon L, Enfors E, Zombré PN (2015) Etats des écosystèmes sahéliens: reverdissement, perte de la biodiversité et qualité des sols. Afr Sci 11(5):433-446

Sileshi GW (2016) The magnitude and spatial extent of influence of Faidherbia albida trees on soil properties and primary productivity in drylands. J Arid Environ 132:1-14

Sileshi G, Akinnifesi FK, Ajayi OC, Place F (2008) Metaanalysis of maize yield response to planted fallow and green manure legumes in sub-Saharan Africa. Plant Soil 307:1-19

Terhoeven-Urselmans T, Vagen T, Spaargaren O, Shepherd KD (2010) Prediction of soil fertility properties from a globally distributed soil mid-infrared spectral library. Development 74(5):1792-1799
Villanueva-López G, Martínez-Zurimendi P, Ramírez-Avilés L, Aryal DR, Casanova-Lug F (2014) Live fences reduce the diurnal and seasonal fluctuations of soil $\mathrm{CO}_{2}$ emissions in livestock systems. Agron Sustain Dev 36:23

Yohannes Y, Shibistova O, Abate A, Fetene M, Guggenberger G (2011) Soil $\mathrm{CO}_{2}$ efflux in an Afromontane forest of Ethiopia as driven by seasonality and tree species. For Ecol Manag 261(6): 1090-1098

Publisher's Note Springer Nature remains neutral with regard to jurisdictional claims in published maps and institutional affiliations. 